\title{
Investigation of the Relationship Between Pre-service Teachers' Critical Thinking Dispositions and Attitudes Towards Socioscientific Issues
}

\author{
Assist. Prof. Dr. Adem Yulmaz \\ Kastamonu University - Turkey \\ ORCID: 0000-0002-1424-8934 \\ e-mail:yilmazadem@kastamonu.edu.tr
}

\author{
Assist. Prof. Dr. Muhammed Salman \\ Kastamonu University - Turkey \\ ORCID: 0000-0003-2144-4842 \\ e-mail:msalman@kastamonu.edu.tr
}

\begin{abstract}
In this study, the relationship between pre-service teachers' critical thinking dispositions and their attitudes towards socioscientific issues was examined. Relational survey method, which is one of the quantitative research approaches, was used in the research process. 813 pre-service teachers from science, mathematics, preschool, psychological counseling and guidance, social sciences, classroom teaching, and fine arts departments studying at education faculties in state universities in the Black Sea Region of Turkey participated in the research. Critical thinking disposition and attitude scales were used as data collection tools in the research. The findings were examined by considering the variables of gender, class level, knowledge about socioscientific issues and the department of education. In the analysis of the data obtained, the results for each scale were first divided into groups as low, medium and high scores. Variables with two categories were analyzed using the independent samples t-test, and variables with more than two categories were analyzed using the ANOVA test. Then, multiple linear regression analyses were performed. Hayes's (2018) regression model number 1 was used to confirm the research results and to support it with advanced statistics. As a result of the research, it was determined that the preservice teachers with low and medium critical thinking dispositions also had low attitudes towards socioscientific issues and sub-variables did not make a significant difference. At this point, some suggestions can be made to pre-service teachers with a low and medium level of critical thinking disposition. It can be ensured that they participate in project activities on socioscientific issues during the training process. It can be ensured that courses within the scope of critical and analytical thinking are taken. It has also been determined that the preservice teachers with high critical thinking disposition have high attitudes towards socioscientific issues, and there is a significant difference in terms of the variables of the department, grade level and having knowledge about socioscientific issues.
\end{abstract}

Keywords: Critical Thinking Disposition, Socioscientific Issues, Relational Survey, Regression Model

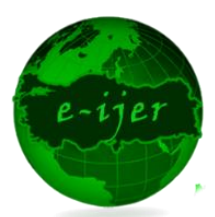

E-International Journal of Educational Research

Vol: 13, No: 1, pp.203-219

Research Article

Received: 2022-01-06 Accepted: 2022-02-17

\section{Suggested Citation}

Yılmaz, A., \& Salman, M. (2022). Investigation of the relationship between pre-service teachers' critical thinking dispositions and attitudes towards socioscientific issues. E-International Journal of Educational Research, 13 (1), 203-219. DOI: https://doi.org/10.19160/e-ijer.1054393 


\section{INTRODUCTION}

When we consider that human life has changed dramatically with the rapid development of technology particularly within the last 30 years and that the age we are currently living in is entitled Post-Truth, critical thinking, which is underpinned in Paul's (1990) popular book as; "What is required for every human being to survive in a rapidly changing world" arguably has never been more important in life. The Post-Truht era indeed is the period when individuals disagree with facts and act according to personal beliefs and feelings rather than tested and validated information whilst making decisions of various sort (Sinatra \& Lombardi, 2020). It is clear that the understanding of 'knowledge is power' has lost its prominence in this period. Because it is becoming increasingly difficult to distinguish between true and false information (Wineburg \& McGrew, 2017). In addition, misinterpretation of information and rejection of scientific evidence are characteristics of the Post-Truth era (Kienhues, Jucks \& Bromme, 2020). Researchers emphasize that tomorrow's adults will have to solve different problems due to the existential crises they will face (Abraham, 2016; Burnard, Colucci-Gray \& Sinha, 2021). Thereupon we need to consider making these predictions in the most appropriate way about the future. In the same line of thought Goodlad (1984) underscored the viability of the process we are in and said that adolescents who are not engaged in critical or high-level thinking cannot be well prepared for the future society and globalization.

Socioscientific Issues (SSI), which consist of real-world problems such as climate change, genetically modified organisms, vaccination, are the leading problems highlighted by researchers (Tyrrell \& Calinger, 2020). The emergence of novel socioscientific issues that affect almost every aspect of human life as well as their future becomes inevitably in parallel with the development of technology and science (Lee, Abd-El-Khalick \& Choi, 2006). The reason here is that the most important feature of socioscientific issues is that they consist of controversial social issues that include science and are based on science (Sadler \& Zeidler, 2005; Topçu, 2010). It is whence necessary to gain a critical perspective in order to be able to make healthy decisions about socioscientific issues. Critical Thinking (CT) is fundamental in making decisions about socioscientific issues (Yacoubian \& Khishfe, 2018) and thusly come into play at this point. By developing critical thinking skills of individuals, it is possible to assist in their critically evaluating socioscientific issues that they will encounter in daily life and also those that will affect their lives, and more importantly, this will help them to make informed and calculated decisions based on knowledge (Sadler \& Zeidler, 2005; Topçu, 2019).

We know that no one can become an expert with the information given in lectures on socioscientific issues such as global warming and vaccination. However, the point is that we have to take a position on such controversial issues without being an expert, as is the case with the COVID-19 pandemic we are currently experiencing. Although we cannot have all the relevant information pertaining to a phenomenon, we can still think critically about that very subject at least to some extent (Ennis, 2018). To cite an example, we can decide to get vaccinated (Ageitos \& Puig, 2021). It is noteworthy that here CT facilitates students' in-depth understanding of specific subject content (Williams, Oliver \& Stockdale, 2004) like this, and fosters advanced decision-making about complex real-life problems (Halpern, 1993; Ennis, 1996; Dwyer, Hogan \& Stewart, 2012) in a more general fashion. In fact, it is closely linked to the tendency to be(come) an active and informed citizen (Tsui, 1999; Puig, Blanco-Anaya \& Pérez-Maceira, 2021).

\section{Theoretical Framework}

In recent years, many countries have been endeavoring to aid in the development of critical thinking skills at all educational levels (Facione, Sanchez, Facione \& Gainen, 1995; Ennis, 1996; Sadler, Chambers \& Zeidler, 2002; Yang \& Chung, 2009; Fong, Kim, Davis, Hoang \& Kim, 2017; Forawi, 2016; Chan, 2019; Janssen et al., 2019; Kavenuke, Kinyota \& Kayombo, 2020; McPeck, 2016; Ren, Tong, Peng \& Wang, 2020; Bellaera, Weinstein-Jones, Ilie \& Baker, 2021; Salman \& Yılmaz, 2021) and socioscientific issues (Levinson, 2006; Chang \& Chiu, 2008; Topçu, 2019; Friedrichsen, Ke, Sadler \& Zangori, 2021) have been attributed more and more importance and apparently have been integrated into the relevant education programs. The main purpose of this trend is the idea that socioscientific issues will contribute to developing critical thinking. As a matter of fact, developing students' critical thinking is crucial to their academic success. It is generally accepted that doing so will increase the quality of education (Ren et al., 
2020). Although socioscientific issues are one of the relatively new aspects of science education, critical thinking has already been a strategic target of the related field since the beginning of the involvement of science education in the curricula. It is difficult to think of a legitimate science education program that does not at least encourage critical thinking (Sadler, Chambers \& Zeidler, 2002). From the student and academics to the ordinary individual in all settings, everyone can enjoy and is inclined to accepting science without hesitations (Cole, 1992), characterized by a stable consensus within the scientific community and by what is referred to as "core science" (Kampourakis, 2018).

When we take a closer look at the content of socioscientific issues, which are known to consist of real-world problems, we see that they fall into the category of science under investigation, which Cole (1992) calls "frontier science" (Kolstø, 2001). The uncertainties that emerged in this process, which evolved from frontier science to core science, and the differences amongst the opinions of the experts, create confusion this time again for everyone viz. from the student and the academic to the ordinary citizen.

Scientific knowledge seemingly tends to leave its place to misinformation and conspiracy theories (Nguyen \& Catalan, 2020). Such misinformation and conspiracy theories represent a health hazard due to their destabilizing potential and power in manipulating decision-making in socioscientific issues as well as recent issues such as vaccination and vaccination behavior (Čavojová, Šrol \& Jurkovič, 2020; Salali \& Uysal, 2020). Countering unscientific and/or pseudoscientific beliefs about socioscientific issues by teaching critical thinking is of utmost importance for the stability and health of society (Wilson, 2018). It has been suggested by a fair number of scholars that socioscientific issues can constitute a sloid ground; a context to explain the social problems posed by scientific developments (Yahaya, Zain \& Karpudewan, 2015; Karışan \& Zeidler, 2017; Hancock et al., 2019). In an age where sources of information (and misinformation) are proliferating, critical thinking must be applied more frequently and in a variety of fields. It goes without saying that in the digital world where multiple facts and truths, opinions, theories and assumptions compete, critical thinking becomes even more important (Halpern, 1999; Chan, 2019; OECD, 2019; Bravo, Galiana, Rodrigo, Navarro-Pérez \& Oliver, 2020; Sinatra \& Lombardi, 2020; Bellaera et al., 2021). Within this context, in response to the call of the information age, universities, as leading centers of scientia, must overcome the challenge of raising future critical thinkers (Chan, 2019; Salman \& YIlmaz, 2021).

The critical thinking process begins with the perspective of viewing the critical person as a critical consumer of information. This includes using rationality to judge between true and false, identify hasty generalizations, to elicit unreliable authority, distinguish reliable and unreliable information, and conduct argument analysis (Davies, 2015). Critical thinking is put simply as the ability to make a logical decision on a subject based on known factual evidence (Bensley, 1998). Critical thinking contributes to the development of one's ability to ask questions, solve problems and make decisions, and the disposition to use these capacities (Dwyer, Hogan, Harney \& Kavanagh, 2017; Nonis \& Hudson, 2019). Ennis (2018) accentuated that critical thinking is reflective and logical thinking that focuses on decisions. In this way, critical thinking emerges as a fundamental thinking skill that one uses to make a logical decision. This is because critical thinking is effective not only in the individual's, to illustrate a student's success in the field of education, but also in their work in other possible social or interpersonal contexts.

Students make decisions about personal or social issues in the society they live in and both require critical thinkings skills, irrespective of their being about personal or societal issues. Therefore, it would be fair to state that all students need critical thinking skills (experience) (Zeidler, Lederman \& Taylor, 1992). That being said, merelt the teaching of said skills may not be adequate on the condition these students are not apt to using their critical thinking skills. Critical thinking is more than the successful use of the right skill in an appropriate context. It is also an attitude or disposition that makes it possible to recognize when a skill is needed and the willingness to exert the mental effort required to practice it (Halpern, 1999). Critical thinking Dispositions then reveal an individual's willingness to use critical thinking skills. Critical thinking enables one to realize how well the skills are performed or not (Facione, Facione \& Giancarlo, 2000; Pitpiorntapin \& Topçu, 2016). It is essential to make decisions about socioscientific issues (as is the sace with; vaccines and vaccinations) that consist of real-world problems, in particular when considering the 'information pollution' and conspiracy theories that have come to the surface in the pandemic. Critical thinking is a special type of inquiry that students will engage in as they 
learn how to make decisions on socioscientific issues. The existence of a mutually triggering relationship between socioscientific issues and critical thinking tendencies is clearly witnessed when studies on socioscientific issues and critical thinking are scrutinized (Sadler, Romine \& Topçu, 2016). In fact, there is a good number of studies conducted on the development of critical thinking in educational programs in which socioscientific issues are integrated (Sadler, Chambers \& Zeidler, 2002; Tal \& Kedmi, 2006; Zeidler \& Nichols, 2009; Domenech \& Marquez, 2013; Eggert, Ostermeyer, Hasselhorn \& Bögeholz, 2013; Pratiwi, Rahayu \& Fajaroh, 2016; Torres \& Solbes, 2016; Sjoström \& Eilks, 2018; Evagorou \& Dillon, 2020; Levrini et al., 2020; Alfitriyani, Pursitasari \& Kurniasih, 2021; Puig, Blanco-Anaya \& Pérez-Maceira, 2021). Likewise, many studies emphasise the role of critical thinking disposition for forming the decisionmaking process on socioscientific issues consisting of real-world problems (Yacoubian, 2015; Ennis, 2018; Gul \& Akcay, 2020; Jafari, Azizi, Soroush \& Khatony, 2020; Puig, Blanco-Anaya \& Pérez-Maceira, 2021; Karışan \& Yılmaz, 2021)

Socioscientific issues, in a way, include subjects that individuals cannot perceive without critical thinking, for which they cannot easily establish a context or to which they are able to produce solutions. But, more importantly, they cannot make the right decisions. Therefore, socioscientific issues, which are important in forming scientific literacy, will not turn into gains in individuals without the regulating function of critical Thinking an inherent element in science. It can be punctuated that there exists a relationship between critical thinking dispositions and socioscientific issues and taking glance at the bulk of literature, we can easily say there is a mutually triggering relationship between socioscientific issues and critical thinking disposition.

\section{Importance of Study}

A large part of the studies in the literature have been comprehensively examined, and it has been observed that the research points to the importance of socioscientific issues in developing critical thinking and the importance of critical thinking in making decisions on socioscientific issues. Attitudes towards socio-scientific issues and critical thinking skills are two different components that complement each other. These skills allow individuals to approach events from different perspectives. Individuals need to have a certain level of attitude towards socio-scientific issues in order to keep up with the society and exhibit effective citizenship. This attitude is possible with the ability to think critically and inquiringly. It is stated in the literatüre that socio-scientific subject-based practices indirectly increase critical thinking skills (Sadler et al., 2002; Zeidler \& Nichols, 2009; Domenech \& Marquez, 2013; Alfitriyani et al., 2021; Puig et al., 2021). Howbeit, seemingly research on the level of the relationship between attitudes towards socioscientific issues and critical thinking dispositions has hitherto been not adequate. For this reason, a direct examination of the relationship between socio-scientific subject-based practices and critical thinking skills was conducted. Socio-scientific subject-based practices and critical thinking skills are essential for gaining scientific literacy. To this end, in this study, this subject was intended to be examined and a model was attempted to be established between attitudes towards socioscientific issues and critical thinking dispositions.

\section{METHOD}

\section{Participants and Procedures}

In this study, the relational survey method, which is one of the quantitative research approaches, was employed. In general, it is possible to reach large masses in the survey method and hence this is frequently preferred in the literature because it provides data richness and other types of conveniences for researchers (Fraenkel, Wallen \& Hyun, 2019). 813 pre-service teachers' studying science, mathematics, preschool, psychological counseling and guidance, social sciences, classroom teaching, and fine arts at state universities in the Black Sea Region of Turkey participated in the research. 55.8\% $(n=453)$ of the participants were women and $44.2 \%(n=360)$ were men. When the participants were examined in terms of grade level, 21.64\% $(n=176)$ were in the $1^{\text {st }}$ grade, $24.84 \%(n=202)$ were in the $2^{\text {nd }}$ grade, $30.14 \%(n=245)$ were in the $3^{\text {rd }}$ grade, and $23.38 \%(n=190)$ in were the $4^{\text {th }}$ grade. During the research process, two different scales were applied to the pre-service teachers'. These scales are attitude and critical thinking disposition scales. In sum, within the scope of the research, critical thinking 
dispositions of pre-service teachers and their attitudes towards socioscientific issues were studied by considering different variables.

\section{Measures}

\section{Attitudes towards Socioscientific Issues Scale (SSI)}

The Attitudes towards Socioscientific Issues Scale developed by Topçu (2010), consisting of 30 items and three dimensions (interest and usefulness of SSI, liking of SSI, anxiety towards SSI) was used to determine the attitudes of the participants towards socioscientific issues. Necessary permissions have been obtained from the owner for the use of the scale. Scale items were grouped between 1-5 and graded between Strongly Disagree and Strongly Agree opinions. The lowest score that can be obtained from the scale is 30 and the highest score is 150 .

\section{Marmara Critical Thinking Dispositions Scale (MCTDS)}

Developed by Ozgenel \& Cetin (2018) Marmara Critical Thinking Dispositions Scale (MCTDS) was used to identify critical thinking dispositions. MCTDS is prepared in likert type and involves 6 factors (reasoning, reaching judgment, search evidence, search the truth, open-mindedness and systematiccity) and 28 items. The score ranges of the scale vary between 28 and 140 . Scale items were graded as never, rarely, occasionally, usually, and always.

\section{Data Analysis}

The results obtained for each scale used in the research were first divided into groups as low, medium, and high scores. Variables with two categories were analyzed using the independent samples t-test, and variables with more than two categories were analyzed using the ANOVA test. Then, multiple linear regression analysis was performed. The dependent variable of the study is attitudes towards socioscientific issues. The independent variables are critical thinking disposition, gender, grade level, department of education and having knowledge about socioscientific issues. During these analyses, it was first examined whether the preconditions were met. Accordingly, it was determined that the results of the scale showed a normal distribution, that each of the predictive variables had a linear relationship with the predicted variable, that the predicted changes were independent of each other, and finally that the differences between the predicted values and the observed values displayed a normal distribution. Hayes's (2018) regression model number 1 was adopted to confirm the results and support them with advanced statistics. The obtained results were analyzed with the help of the SPSS 25.0 program and PROCESS Macro extension. The PROCESS macro for the SPSS was used to analyze the model used to socioscientific issues and critical thinking. In addition, a correlational analysis application was also carried out. The confidence interval was taken as $95 \%$ in the research.

\section{FINDINGS}

\section{Findings for Marmara Critical Thinking Dispositions Scale}

Table 1 presents the results for the two-category variables. Table 2 presents results for variables with more than two categories.

Table 1. Findings for two-category variables (MCTDS)

\begin{tabular}{|c|c|c|c|c|c|c|c|}
\hline \multirow[t]{2}{*}{ Score Level } & \multirow[t]{2}{*}{ Variable } & \multirow[t]{2}{*}{ Sub-Variable } & \multicolumn{5}{|c|}{ Independent Samples T-Test } \\
\hline & & & $\bar{x}$ & $S D$ & $T$ & $p$ & Diff. \\
\hline \multirow{4}{*}{ Low Score } & \multirow[t]{2}{*}{ Gender } & Female & 3.65 & .272 & \multirow{2}{*}{-.885} & \multirow{2}{*}{.378} & \multirow{2}{*}{-} \\
\hline & & Male & 3.62 & .288 & & & \\
\hline & \multirow{2}{*}{ To have knowledge about SSI } & Yes & 3.67 & .261 & \multirow{2}{*}{-1.666} & \multirow{2}{*}{.097} & \multirow{2}{*}{-} \\
\hline & & No & 3.61 & .294 & & & \\
\hline \multirow{5}{*}{ Middle Score } & \multirow{3}{*}{ Gender } & & $\bar{X}$ & $S D$ & $T$ & $p$ & Diff. \\
\hline & & Female & 4.15 & .132 & \multirow{2}{*}{-.251} & \multirow{2}{*}{.802} & \multirow{2}{*}{-} \\
\hline & & Male & 4.14 & .131 & & & \\
\hline & \multirow{2}{*}{ To have knowledge about SSI } & Yes & 4.17 & .128 & \multirow{2}{*}{-.030} & \multirow{2}{*}{.976} & \multirow{2}{*}{ - } \\
\hline & & No & 4.15 & .140 & & & \\
\hline \multirow{5}{*}{ High Score } & \multirow{3}{*}{ Gender } & & $\bar{X}$ & $S D$ & $T$ & $p$ & Diff. \\
\hline & & Female & 4.70 & .191 & \multirow{2}{*}{.488} & \multirow{2}{*}{.626} & \multirow{2}{*}{-} \\
\hline & & Male & 4.72 & .201 & & & \\
\hline & \multirow{2}{*}{ To have knowledge about SSI } & Yes & 4.85 & .263 & \multirow{2}{*}{6.452} & \multirow{2}{*}{.002} & \multirow{2}{*}{$\checkmark$} \\
\hline & & No & 3.76 & .086 & & & \\
\hline
\end{tabular}


When Table 1 is examined, it is seen that the results of the critical thinking disposition scale are significant solely for pre-service teachers with high scores in terms of two-category variables. This significance was in favor of the variable of having knowledge about socioscientific issues $\left[t_{(811)}=6.452\right.$, $p=.002<.05]$. Those who have previous knowledge about socioscientific issues make a significant difference in their critical thinking disposition.

Table 2. Findings for variables with more than two categories (MCTDS)

\begin{tabular}{|c|c|c|c|c|c|c|}
\hline \multirow[t]{2}{*}{ Score Level } & \multirow[t]{2}{*}{ Variable } & \multicolumn{5}{|c|}{ One-Way ANOVA } \\
\hline & & & Sum of Squares & $F$ & $p$ & Diff. \\
\hline \multirow{6}{*}{ Low Score } & \multirow{3}{*}{ Grade level } & Between Groups & .195 & & & \\
\hline & & Within Groups & 20.469 & .849 & .468 & - \\
\hline & & Total & 20.664 & & & \\
\hline & \multirow{3}{*}{ Department } & Between Groups & .291 & & & \\
\hline & & Within Groups & 22.658 & 1.051 & .385 & - \\
\hline & & Total & 22.949 & & & \\
\hline \multirow{7}{*}{ Middle Score } & \multirow{4}{*}{ Grade level } & & Sum of Squares & $F$ & $p$ & Diff. \\
\hline & & Between Groups & .036 & & & \\
\hline & & Within Groups & 4.655 & .696 & .554 & - \\
\hline & & Total & 4.691 & & & \\
\hline & \multirow{3}{*}{ Department } & Between Groups & .139 & & & \\
\hline & & Within Groups & 6.179 & .796 & .429 & - \\
\hline & & Total & 6.318 & & & \\
\hline \multirow{7}{*}{ High Score } & \multirow{4}{*}{ Grade level } & & Sum of Squares & $F$ & $p$ & Diff. \\
\hline & & Between Groups & 37.289 & & & \\
\hline & & Within Groups & 348.965 & 21.568 & .001 & $\checkmark$ \\
\hline & & Total & 386.254 & & & \\
\hline & \multirow{3}{*}{ Department } & Between Groups & 29.756 & & & \\
\hline & & Within Groups & 326.774 & 19.567 & .000 & $\checkmark$ \\
\hline & & Total & 356.530 & & & \\
\hline
\end{tabular}

Diff: Difference, SD: Std. Deviation, ${ }^{*} p<.05$

When Table 2 is examined, it is observed that the results of the critical thinking disposition scale are significant only for the pre-service teachers with high scores as regards multi-category variables. This significance was in favor of class level $\left[F_{(4-808)}=21.568, p=.001^{*}<.05\right]$ and department of education variables $\left[F_{(6-806)}=19.567, p=.000^{*}<.05\right]$. As the grade level increases, so does the disposition to think critically. It has been determined that pre-service teachers who study at? science, mathematics and social sciences departments have a higher disposition to think critically.

\section{Findings of the Attitude Scale towards Socioscientific Issues}

Table 3 presents the results for the two-category variables. Results for variables with more than two categories are presented in Table 4.

Table 3. Findings for two-category variables (SSI)

\begin{tabular}{|c|c|c|c|c|c|c|c|}
\hline \multirow[t]{2}{*}{ Score Level } & \multirow[t]{2}{*}{ Variable } & \multirow[t]{2}{*}{ Sub-Variable } & \multicolumn{5}{|c|}{ Independent Samples T-Test } \\
\hline & & & $\bar{X}$ & $S D$ & $T$ & $p$ & Diff. \\
\hline \multirow{4}{*}{ Low Score } & Gender & Female & 3.21 & .324 & \multirow{2}{*}{-.848} & \multirow[b]{2}{*}{.398} & \multirow{2}{*}{-} \\
\hline & & Male & 3.17 & .335 & & & \\
\hline & \multirow{2}{*}{$\begin{array}{l}\text { To have knowledge } \\
\text { about SSI }\end{array}$} & Yes & 3.25 & .284 & \multirow{2}{*}{-3.476} & \multirow{2}{*}{.001} & \multirow{2}{*}{$\sqrt{ }$} \\
\hline & & No & 3.11 & .366 & & & \\
\hline \multirow{5}{*}{ Middle Score } & \multirow{3}{*}{ Gender } & & $\bar{X}$ & $S D$ & $T$ & $p$ & Diff. \\
\hline & & Female & 3.34 & .342 & \multirow{2}{*}{.272} & \multirow{2}{*}{.786} & \multirow{2}{*}{-} \\
\hline & & Male & 3.35 & .333 & & & \\
\hline & \multirow{2}{*}{$\begin{array}{l}\text { To have knowledge } \\
\text { about SSI }\end{array}$} & Yes & 3.37 & .318 & \multirow{2}{*}{-1.576} & \multirow{2}{*}{.118} & \multirow{2}{*}{-} \\
\hline & & No & 3.29 & .383 & & & \\
\hline \multirow{5}{*}{ High Score } & \multirow{3}{*}{ Gender } & & $\bar{X}$ & $S D$ & $T$ & $p$ & Diff. \\
\hline & & Female & 3.48 & .326 & \multirow{2}{*}{-.304} & \multirow{2}{*}{.762} & \multirow{2}{*}{-} \\
\hline & & Male & 3.46 & .383 & & & \\
\hline & \multirow{2}{*}{$\begin{array}{l}\text { To have knowledge } \\
\text { about SSI }\end{array}$} & Yes & 3.79 & .226 & \multirow{2}{*}{4.196} & \multirow{2}{*}{.001} & \multirow{2}{*}{$\checkmark$} \\
\hline & & No & 3.14 & .171 & & & \\
\hline
\end{tabular}

Diff: Difference, $S D$ : Std. Deviation, ${ }^{*} p<.05$ 
When Table 3 is examined, it is found out that the results of the attitude scale towards socioscientific issues are significant with respect to two-category variables for pre-service teachers with low and high scores. This significance was in favor of having knowledge about socioscientific issues $\left[\mathrm{t}_{(811)}=-3.476, p=.001<.05\right],\left[\mathrm{t}_{(811)}=4.196, p=.001<.05\right]$. Socioscientific issues were found in favor of those who answered "yes" in individuals with low mean. There was a significant difference between pre-service teachers with high grade point averages in favor of those with previous knowledge about socioscientific issues.

Table 4. Findings for variables with more than two categories (SSI)

\begin{tabular}{|c|c|c|c|c|c|c|}
\hline \multirow{2}{*}{ Score Level } & \multirow[t]{2}{*}{ Variable } & \multicolumn{5}{|c|}{ One-Way ANOVA } \\
\hline & & & Sum of Squares & $F$ & $p$ & Diff. \\
\hline \multirow{6}{*}{ Low Score } & \multirow{3}{*}{ Grade level } & Between Groups & .113 & & & \\
\hline & & Within Groups & 28.829 & .349 & .790 & - \\
\hline & & Total & 28.942 & & & \\
\hline & \multirow{3}{*}{ Department } & Between Groups & .693 & & & \\
\hline & & Within Groups & 34.128 & .996 & .378 & - \\
\hline & & Total & 34.821 & & & \\
\hline \multirow{7}{*}{ Middle Score } & \multirow{4}{*}{ Grade level } & & Sum of Squares & $F$ & $p$ & Diff. \\
\hline & & Between Groups & .274 & & & \\
\hline & & Within Groups & 30.802 & .793 & .499 & - \\
\hline & & Total & 31.080 & & & \\
\hline & \multirow{3}{*}{ Department } & Between Groups & 39.777 & & & \\
\hline & & Within Groups & 376.121 & 24.756 & .001 & $\checkmark$ \\
\hline & & Total & 415.898 & & & \\
\hline \multirow{7}{*}{ High Score } & \multirow{4}{*}{ Grade level } & & Sum of Squares & $F$ & $p$ & Diff. \\
\hline & & Between Groups & 31.742 & & & \\
\hline & & Within Groups & 341.239 & 22.158 & .000 & $\checkmark$ \\
\hline & & Total & 372.981 & & & \\
\hline & \multirow{3}{*}{ Department } & Between Groups & 36.425 & & & \\
\hline & & Within Groups & 346.921 & 25.147 & .004 & $\checkmark$ \\
\hline & & Total & 383.346 & & & \\
\hline
\end{tabular}

Diff: Difference, SD: Std. Deviation, ${ }^{*} p<.05$

When Table 4 is examined, it is understood that the results of the attitude scale towards socioscientific issues are significant with regard too multi-category Variables for? pre-service teachers with medium and high scores. This level of significance is grade level $\left[\mathrm{F}_{(4-808)}=22.158, p=.000^{*}<.05\right]$ and department of education variables $\left[\mathrm{F}_{(6-806)}=24.756, p=.000^{*}<.05\right],\left[\mathrm{F}_{(6-806)}=25.147, p=.004^{*}<.05\right]$. As the grade level increases, the disposition to think critically increases. Pre-service science, mathematics and social sciences teachers, at department level, exhibit a higher disposition to think critically.

\section{Findings for Correlation and Multiple Linear Regression Analysis}

Table 5 demonstrates the correlation results for the research variables. The results for multiple linear regression analyses are presented in Table 6.

Table 5. Correlation between variables and descriptive statistics results

\begin{tabular}{|c|c|c|c|c|c|c|}
\hline Variable & 1 & 2 & 3 & 4 & 5 & 6 \\
\hline 1. MCTDS & - & & & & & \\
\hline 2. SSI & $.334^{* *}$ & - & & & & \\
\hline 3. Gender & .043 & .028 & - & & & \\
\hline 4. Grade level & .064 & $.198^{\star \star *}$ & -.002 & - & & \\
\hline 5. To have knowledge about SSI & $.139^{\star *}$ & $.174^{\star *}$ & .009 & .003 & - & \\
\hline 6. Department & $.325^{\star \star}$ & $.159^{\star \star}$ & $.087^{\star}$ & .064 & $.130^{\star \star}$ & - \\
\hline M & 4.17 & 3.34 & - & - & - & - \\
\hline 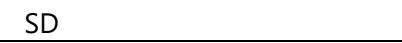 & .480 & .354 & - & - & - & - \\
\hline
\end{tabular}

When Table 5 is delved into, it is encountered that the highest correlation is between SSI and MCTDS and at a positive level $\left(r=.334^{* *}, p<.01\right)$. At the same time, it is detected that there is a positive correlation $\left(r=.198^{* *}, p<.01\right)$ between SSI and grade level. Gender variable, on the other hand, does not show a positive correlation with other sub-variables. Knowledge of socioscientific issues variable was positively correlated with both MCTDS $(r=.139 * *, p<.01)$ and SSI $\left(r=.174^{* *}, p<.01\right)$. Department of 
education variable MCTDS $\left(r=.325^{* *}, p<.01\right)$, SSI $\left(r=.159^{* *}, p<.01\right)$ and knowledge of socioscientific issues $\left(r=.130^{\star \star}, p<.01\right)$ has a positive correlation.

Table 6. Multiple linear regression results for research variables

\begin{tabular}{|c|c|c|c|c|c|c|c|}
\hline Variables & B & SE & $\beta$ & $\mathbf{t}$ & $\mathbf{p}$ & Zero-Order & Partial $\mathbf{r}$ \\
\hline (Constant) & 2.030 & .153 & - & 13.308 & .000 & - & - \\
\hline MCTDS & .221 & .026 & .300 & 8.598 & .000 & .334 & .290 \\
\hline Gender & .008 & .026 & .010 & .308 & .758 & .028 & .011 \\
\hline Grade level & .157 & .032 & .147 & 5.569 & .005 & .198 & .142 \\
\hline To have knowledge about SSI & .098 & .025 & .129 & 3.870 & .000 & .174 & .135 \\
\hline Department & .176 & .027 & .202 & 4.512 & .001 & .159 & .117 \\
\hline
\end{tabular}

Note. Dependent Variable: SSI

$B$ : Unstandardized Coefficient; SE: Std. Error; $\beta$ : Standardized Coefficient; $t$ : t-value;

$P$ : $\mathrm{p}$ - value; $r$ : Correlations Coefficient.

When Table 6 is dwelled upon, it is realized that the attitudes of pre-service teachers towards socioscientific issues $(\beta=.300, p=.000<.05)$, knowledge about socioscientific issues $(\beta=.129, p=.000<.05)$, are predicted by the section $(\beta=.202, p=.001<.05)$ and grade level variable $(\beta=.147, p=.005<.05)$. Among these variables, the highest contribution was made by the disposition to think critically, and the least contribution was made by the variable of having knowledge about socioscientific issues. The gender variable did not make any contribution in this process.

\section{Serial Multiple Moderator Analyses}

In Table 7, the results of the direct and indirect effects of critical thinking disposition on attitudes towards socioscientific issues are presented. Figure- 1 lays out the research model and the status of subvariables.

Table 7. Direct and indirect effect of critical thinking disposition on attitudes towards socioscientific issues

\begin{tabular}{llccccc}
\hline & Variable & $\boldsymbol{R}$ & $\boldsymbol{R}^{\mathbf{2}}$ & $\boldsymbol{p}$ & LLCI & ULCI \\
\hline Direct Effect & MCTDS & .334 & .111 & .000 & 1.538 & 3.123 \\
\hline \multirow{5}{*}{ Indirect Effect } & Int_1 $=X^{\star} W_{1}$ (Gender) & .334 & .111 & .939 & -.102 & .111 \\
& Int_2 $=X^{\star} W_{2}$ (To have knowledge about SSI) & .351 & .123 & .000 & .157 & .305 \\
& Int_3 $=X^{\star} W_{3}$ (Department) & .461 & .213 & .001 & .459 & .806 \\
& Int_4 $=X^{\star} W_{4}$ (Grade level) & .357 & .128 & .005 & .096 & .301 \\
\hline
\end{tabular}

Note. Dependent Variable: SSI; $p$ : p- value; Cl: Confidence interval; LL lower limit; UL upper limit.

Table 7 discloses that critical thinking disposition directly affects the attitude towards socioscientific issues and this effect is at the level of $(R=.334, p<.05)$. However, the gender variable is insignificant and affects at very low levels. While the variable of the department of education indirectly affects the attitude towards socioscientific issues at the highest level, this is followed by the variables of class level and having knowledge about socioscientific issues. The research model and the status of the sub-variables are summarized in Figure 1.

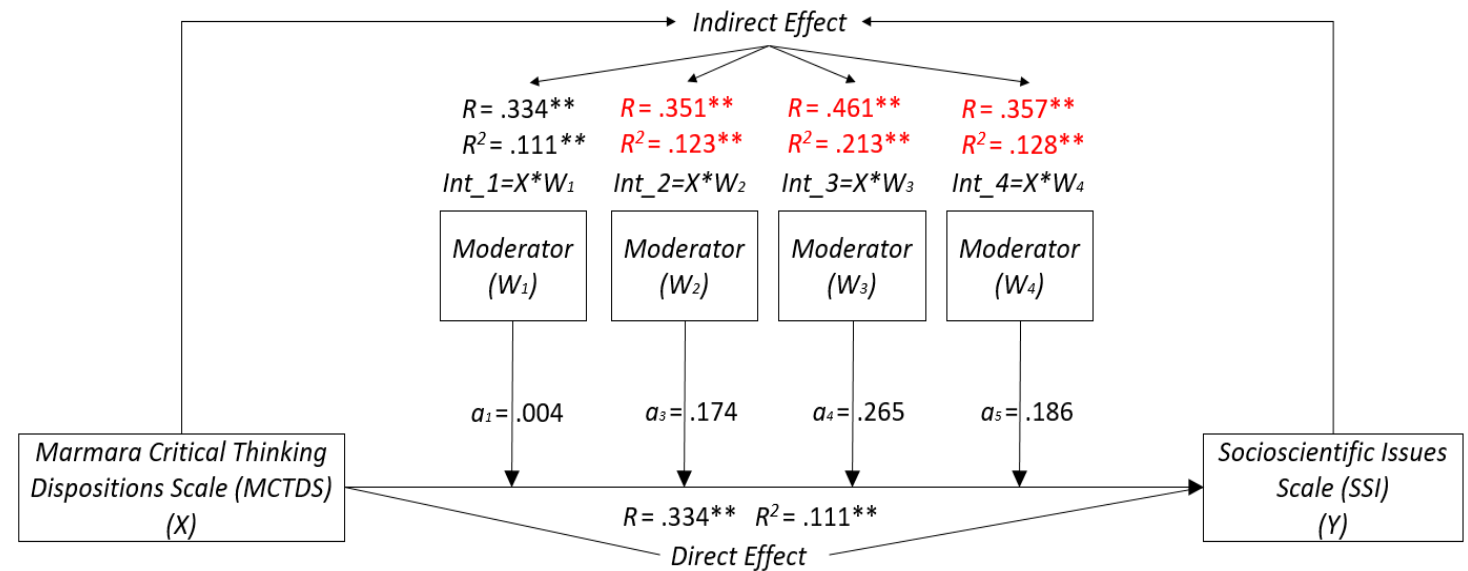

Figure 1. Serial multiple moderational model ${ }^{* *} p<.01$ 


\section{DISCUSSION and CONCLUSION}

We know that the priority in the studies carried out in the field of education and training so far has oftentimes centered on how to increase academic success. That being said, in today's Post-Truth era, issues like how we can survive the pandemics such as the COVID-19, which can affect all people living in the world at the same time, rather than attaining academic success, has inevitably taken over the priority order. Scientists predict that we will be facing more epidemics from now on (Karpudewan \& Chan, 2020). The key to success in survival is to turn the right decisions into behavior using the necessary scientific knowledge. Without doubt, instruction; education and educators are the agents that can assure this behavior change. Thence, many countries have realized the urgency of integrating socioscientific issues and critical thinking into their education programs and have taken steps in this direction (Bellaera et al., 2021; Chan, 2019; Friedrichsen et al., 2021; Forawi, 2016; Kavenuke, Kinyota \& Kayombo, 2020). In this study, it was tried to determine the kind of the relationship that exists between attitudes towards socioscientific issues and critical thinking Dispositions, on which many countries have begun to address, was inquired into.

In our research, first of all, pre-service teachers' attitudes towards socioscientific issues and their critical thinking dispositions were examined separately. It has been observed that the attitudes and critical thinking dispositions of the pre-service teachers towards socioscientific issues are positively significant according to their grade level, department of education, and prior knowledge about socioscientific issues. The fact that both attitudes towards socioscientific issues and critical thinking dispositions are significant, increasing from $1^{\text {st }}$ to $4^{\text {th }}$ grade according to grade levels, can be explained by the fact that pre-service teachers take courses on socioscientific issues and critical thinking during their study at university from the first grade to the last grade. In other studies, it has been revealed along the same lines that attitudes towards socioscientific issues and critical thinking dispositions increase according to grade levels (Shin, Lee, Ha \& Kim, 2006). When the attitudes and critical thinking dispositions of the pre-service teachers towards socioscientific issues are investigated according to the departments they study at, it is uncovered that for those who study science, mathematics and social sciences they are higher than those who study in others (pre-school, psychological counseling and guidance, classroom and fine arts programs). When we pore over the curriculum of science and social sciences teaching departments, subjects like; "The Nature of Science; Critical and Analytical Thinking; Contemporary World Problems; Science, Technology and Society" can be considered as part of the reason why the attitudes and critical thinking dispositions of the pre-service teachers studying in these departments are higher than the pre-service teachers in other departments. This is valid for the findings of some other studies as well (Topçu, 2019).

When the correlation results of the research variables are evaluated, it is discerned that the highest correlation is between socioscientific issues and critical thinking disposition and at a positive level. At the same time, it is unearthed that there is a positive correlation between socioscientific issues and grade level. On the other hand, there was no positive correlation between the gender variable and other subvariables. The variable of having knowledge about socioscientific issues has a positive correlation with both critical thinking disposition and socioscientific issues. The variable of education, critical thinking disposition, attitude towards socioscientific issues and having knowledge about socioscientific issues have positive and high correlations. It is possible to see the relationship between critical thinking and socioscientific issues in other studies. For example, Alfitriani et al. (2021) carried out biotechnology learning activities using a module based on socioscientific issues to determine the increase in the participants' critical thinking skills.

Considering the results of their study, the participants' critical thinking skills increased. In the same way, it is seen in other studies that the socioscientific-based teaching model increases students' critical thinking perceptions (Pratiwi et al., 2016; Wang, Chen, Lin, Huang \& Hong, 2017). The research results were also subjected to advanced statistics. Accordingly, multiple linear regression analyses were performed, and it is spotted that the attitudes of pre-service teachers towards socioscientific issues are predicted apropos of critical thinking disposition, knowledge about socioscientific issues, department of 
education and grade level and have a positive relationship. Attitude towards socioscientific issues was predicted mostly by critical thinking disposition, and least by having knowledge about socioscientific issues variable. The gender variable did not make any contribution in this process.

As a result of the research, it is clear that critical thinking disposition directly affects the attitude towards socioscientific issues. The gender variable is insignificant and has a very low effect. This effect is negligible. The variable of the department studied indirectly affects the attitude towards socioscientific issues at the highest level. In addition, the variables of grade level and knowledge about socioscientific issues also have a positive effect.

\section{IMPLICATIONS}

Reflections of the findings and results over the educational contexts are enlisted in the following way:

1. As pre-service teachers' critical thinking dispositions increase, their attitudes towards socioscientific issues increase in an affirmative and positive way. Sub-variables (gender, grade level and alike) generally do not make a significant difference for individuals with low and medium level of critical thinking disposition. At this point, some suggestions can be made to pre-service teachers with a low and medium level of critical thinking disposition. It can be ensured that they participate in project activities on socioscientific issues during the training process. It can be ensured that courses within the scope of critical and analytical thinking are taken.

2. The variable that most affects the attitude towards socioscientific issues is the variable of department. That being the case, the pre-service teachers with the highest attitudes were respectively science, mathematics, and social sciences education teachers. Therefore, critical and analytical thinking courses and practices related to socioscientific issues should be included in the curricula of departments other than these departments.

3. Another variable that affects pre-service teachers' attitudes towards socioscientific issues is the grade level variable. As the grade level increases, pre-service teachers' attitudes and critical thinking dispositions increase in an affirmative and positive way. For this reason, it can be recommended that pre-service teachers participate in activities related to socio-scientific issues and critical thinking skills from the first to the last year during their university education.

\section{LIMITATIONS and FUTURE RESEARCH}

In this study, pre-service teachers who are involved in raising qualified individuals for the society were preferred. With that being said the attitude towards socioscientific issues and the ability to think critically is an issue that concerns all people living in the world. For this reason, participants from different faculties and even from different walks of life may be preferred in future studies. Another limitation of the study is that it was conducted with university students. Socioscientific issues are closely related to critical thinking skills, which are aimed to be gained at secondary and high school levels. For this reason, it would be very beneficial to perform the study with students at the secondary and high school level too. Finally, socioscientific issues generally consist of issues that do not have a definite solution and that cannot be easily reconciled in society. At this point, it is necessary to give importance to the pedagogical training of individuals at an early age in order to make them think critically and educate them to be open to criticism.

\section{Disclosure of Interest Statement and Ethical Declaration}

The authors herein report that they have no conflict of interest. For all data collection instruments; the scales, all the relevant permissions were obtained from the shareholders and could be documented upon demand.

\section{REFERENCES}

Abraham, A. (2016). Gender and creativity: An overview of psychological and neuroscientific literature. Brain Imaging and Behavior, 10(2), 609-618. https://doi.org/10.1007/s11682-015-9410-8 
Ageitos, N., \& Puig, B. (2021). Critical thinking to decide what to believe and what to do regarding vaccination in schools. A case study with primary pre-service teachers. Critical Thinking in Biology and Environmental Education. Facing Challenges in a Post-Truth World.

Alfitriyani, N., Pursitasari, I. D., \& Kurniasih, S. (2021). Biotechnology module based on sociosaintific issues to improve student's critical thinking ability through online learning. Jurnal Pendidikan Matematika dan IPA, 12(1), 23-39. http://dx.doi.org/10.26418/jpmipa.v12i1.43179

Bellaera, L., Weinstein-Jones, Y., Ilie, S., \& Baker, S. T. (2021). Critical thinking in practice: The priorities and practices of instructors teaching in higher education. Thinking Skills and Creativity, 41,1-16. https://doi.org/10.1016/j.tsc.2021.100856

Bensley, D. A. (1998). Critical thinking in psychology: A unified skills approach. Thomson Brooks/Cole Publishing Co. https://psycnet.apa.org/record/1998-06468-000

Bravo, M. J., Galiana, L., Rodrigo, M. F., Navarro-Pérez, J. J., \& Oliver, A. (2020). An adaptation of the critical thinking disposition scale in Spanish youth. Thinking Skills and Creativity, 38, 1-12. https://doi.org/10.1016/j.tsc.2020.100748

Burnard, P., Colucci-Gray, L., \& Sinha, P. (2021). Transdisciplinarity: Letting arts and science teach together. Curric Perspect, 41, 113-118. https://doi.org/10.1007/s41297-020-00128-y

Chan, Z. C. (2019). Nursing students' view of critical thinking as 'Own thinking, searching for truth, and cultural influences'. Nurse Education Today, 78, 14-18. https://doi.org/ 10.1016/j.nedt.2019.03.015

Chang, S. N., \& Chiu, M. H. (2008). Lakatos' scientific research programmes as a framework for analysing informal argumentation about socio-scientific issues. International Journal of Science Education, 30(13), 1753-1773. https://doi.org/10.1080/095006907 01534582

Čavojová, V., Šrol, J., \& Jurkovič, M. (2020). Why should we try to think like scientists? Scientific reasoning and susceptibility to epistemically suspect beliefs and cognitive biases. Applied Cognitive Psychology, 34(1), 8595. https://doi.org/10.1002/acp.3595

Cole, S. (1992). Making science: Between nature and society. Harvard University Press. https://www.hup.harvard.edu/catalog.php?isbn=9780674543478

Davies, M. (2015). A model of critical thinking in higher education. M.B. Paulsen (Ed.). In Higher education: Handbook of theory and research (pp. 41-92). Springer, Cham. https://doi.org/10.1007/978-3-319-128351 2

Domenech, A. M., \& Marquez, C. (2013). Promoting students' critical thinking through the design of scientific researches related to a SSI: the case of ADHD. ESERA Conference Proceeding. https://gent.uab.cat/conxitamarquez/sites/gent.uab.cat.conxitamarquez/file s/Ana\%20Ma_Dom\%C3\%A8nech_2Feb2014.pdf

Dwyer, C. P., Hogan, M. J., \& Stewart, I. (2012). An evaluation of argument mapping as a method of enhancing critical thinking performance in e-learning environments. Metacognition and Learning, 7(3), 219-244. https://doi.org/10.1007/s11 409-012-9092-1

Dwyer, C. P., Hogan, M. J., Harney, O. M., \& Kavanagh, C. (2017). Facilitating a student-educator conceptual model of dispositions towards critical thinking through interactive management. Educational Technology Research and Development, 65(1), 47-73. http://doi.org/10.1007/s11423-016-9460-7

Eggert, S., Ostermeyer, F., Hasselhorn, M., \& Bögeholz, S. (2013). Socioscientific decision making in the science classroom: The effect of embedded metacognitive instructions on students' learning outcomes. Education Research International, Special Issue, 1-12. https://doi.org/10.1155/2013/309894

Ennis, R. H. (1996). Critical thinking dispositions: Their nature and assessability. Informal Logic, 18(2\&3), 165-182. https://informallogic.ca/index.php/informal_logic/article/vi ew/2378/1820

Ennis, R. H. (2018). Critical thinking across the curriculum: A vision. Topoi, 37(1), 165-184. https://doi.org/10.1007/s11245-016-9401-4

Evagorou, M., \& Dillon, J. (2020) Introduction: Socio-scientific issues as promoting responsible citizenship and the relevance of science. In: Evagorou M., Nielsen J., Dillon J. (eds). Science Teacher Education for Responsible Citizenship. Contemporary Trends and Issues in Science Education (pp.1-11), Vol 52. Springer, Cham. https://doi.org/10.1007/978-3-030-40229-7_1

Facione, P. A., Facione, N. C., \& Giancarlo, C. A. F. (2000). The California critical thinking disposition inventory: CCTDI test manual. California Acad. Press.

https://scholar.google.com/citations?view_op=view_citation\&hl=en\&user=7oqEut0AAAAJ\&citation_for_vie w=7oqEut0AAAAJ:u-x6o8ySG0sC 
Facione, P. A., Sanchez, C. A., Facione, N. C., \& Gainen, J. (1995). The disposition toward critical thinking. The Journal of General Education, 44(1), 1-25. https://www.insightassessment.com/wpcontent/uploads/ia/pdf/Disposition_to_CT_19 95_JGE.pdf

Fong, C. J., Kim, Y., Davis, C. W., Hoang, T., \& Kim, Y. W. (2017). A meta-analysis on critical thinking and community college student achievement. Thinking Skills and Creativity, 26, 71-83. https://doi.org/10.1016/j.tsc.2017.06.002

Forawi, S. A. (2016). Standard-based science education and critical thinking. Thinking Skills and Creativity, 20, 5262. http://dx.doi.org/10.1016/j.tsc.2016.02.005

Fraenkel, J. R., Wallen, N. E., \& Hyun, H. H. (2019). How to design and evaluate research in education (10 ${ }^{\text {th }}$ Edition). McGraw-Hill. https://www.mheducation.com/highered/ product/how-design-evaluate-research-educationfraenkel-wallen/M9781259913839. html

Friedrichsen, P. J., Ke, L., Sadler, T. D., \& Zangori, L. (2021). Enacting co-designed socio-scientific issues-based curriculum units: A case of secondary science teacher learning. Journal of Science Teacher Education, 32(1), 85-106. https://doi.org/10.1080/1046560X.2020.1795576

Goodlad, J. (1984). A place called school' Prospects for the future. McGraw-Hill. https://academic.oup.com/cs/article-abstract/6/3/213/352529?redirectedFrom=fulltext

Gul, M. D., \& Akcay, H. (2020). Structuring a new socioscientific issues (SSI) based instruction model: Impacts on pre-service science teachers' (PSTs) critical thinking skills and dispositions. International Journal of Research in Education and Science, 6(1), 141-159. https://doi.org/10.46328/ijres.v6i1.785

Halpern, D. F. (1993). Assessing the effectiveness of critical-thinking instruction. The Journal of General Education, 42(4), 238-254. https://www.deepdyve.com/lp/psu_press/asses sing-the-effectiveness-of-criticalthinking-instruction-vz9ltc0jLB

Halpern, D. F. (1999). Teaching for critical thinking: Helping college students develop the skills and dispositions of a critical thinker. New Directions for Teaching and Learning, 80, 69-74. https://doi.org/10.1002/tl.8005

Hancock, P. A., Kaplan, A. D., Cruit, J. K., Hancock, G. M., MacArthur, K. R., \& Szalma, J. L. (2019). A meta-analysis of flow effects and the perception of time. Acta Psychologica, 198, 1-18. https://doi.org/10.1016/j.actpsy.2019.04.007

Hayes, A. F. (2018). Introduction to mediation, moderation, and conditional process analysis: A regression based approach. Guilford Publications. https://www.guilford.com/books/ Introduction-to-Mediation-Moderationand-Conditional-Process-Analysis/Andrew-Hayes/9781462534654

Jafari, F., Azizi, S. M., Soroush, A., \& Khatony, A. (2020). Critical thinking level among medical sciences students in Iran. Education Research International, 1-18. https://doi.org/10.1155/2020/1348365

Janssen, E. M., Mainhard, T., Buisman, R. S., Verkoeijen, P. P., Heijltjes, A. E., van Peppen, L. M., \& van Gog, T. (2019). Training higher education teachers' critical thinking and attitudes towards teaching it. Contemporary Educational Psychology, 58, 310-322. https://doi.org/10.1016/j.cedpsych.2019.03.007

Kampourakis, K. (2018). Science and uncertainty. Science \& Education, 27(9), 829-830. https://doi.org/10.1007/s11191-018-0019-3

Karışan, D., \& Zeidler, D. L. (2017). Contextualization of nature of science within the socioscientific issues framework: A review of research. International Journal of Education in Mathematics, Science and Technology, 5(2), 139-152. https://doi.org/10.18404/ijemst.270186

Karışan, D., \& Yılmaz, A. (2021). Uzaktan eğitimde STEM uygulamalarının sosyobilimsel konular açısından incelenmesi. A. Yılmaz, B. Ertuğrul-Akyol ve M. N. Aydede (Edts). Uzaktan eğitim sürecinde örnek etkinliklerle STEM uygulamaları içinde (s. 139-164). Pegem Akademi Yayınları.

Karpudewan, M., \& Chan, L. H. (2020). Educating primary students on infectious diseases and nurturing character and values using socioscientific instruction. Journal of Public Health: From Theory to Practice, 1-11. https://doi.org/10.1007/s10389-020-01368-y

Kavenuke, P. S., Kinyota, M., \& Kayombo, J. J. (2020). The critical thinking skills of prospective teachers: Investigating their systematicity, self-confidence and scepticism. Thinking Skills and Creativity, 37, 1-11. https://doi.org/10.1016/j.tsc.2020. 100677

Kienhues, D., Jucks, R., \& Bromme, R. (2020). Sealing the gateways for post-truthism: Reestablishing the epistemic authority of science. Educational Psychologist, 55(3), 144-154. https://doi.org/10.1080/00461520.2020.1784012

Kolstø, S. D. (2001). Scientific literacy for citizenship: Tools for dealing with the science dimension of controversial socioscientific issues. Science education, 85(3), 291-310. https://doi.org/10.1002/sce.1011 
Lee, H., Abd-El-Khalick, F., \& Choi, K. (2006). Korean science teachers' perceptions of the introduction of socioscientific issues into the science curriculum. Canadian Journal of Math, Science \& Technology Education, 6(2), 97-117. https://doi.org/10.1080/ 14926150609556691

Levinson, R. (2006). Towards a theoretical framework for teaching controversial socio-scientific issues. International Journal of Science Education, 28(10), 1201-1224. https://doi.org/10.1080/09500690600560753

Levrini, O., Tasquier, G., Barelli, E., Laherto, A., Palmgren, E., Branchetti, L., \& Wilson, C. (2020). Recognition and operationalization of future-scaffolding skills: Results from an empirical study of a teaching-learning module on climate change and futures thinking. Science Education, 105(2), 281-308.

https://doi.org/10.1002/sce.21612

McPeck, J.E. (2016). Teaching critical thinking: Dialogue and dialectic (E-Book). Routledge. https://doi.org/10.4324/9781315526492

Nguyen, A., \& Catalan, D. (2020). Digital mis/disinformation and public engagment with health and science controversies: Fresh perspectives from COVID-19. Media and Communication, 8(2), 323-328. https://doi.org/10.17645/mac.v8i2.3352

Nonis, S. A., \& Hudson, G. I. (2019). Developing and assessing critical thinking skills in marketing students: The power of making explicit problem-solving processes. Journal of Education for Business, 94(3), 195-203. https://doi.org/10.1080/08832323.2018. 1504737

OECD (2019). OECD learning compass 2030: A series of concept notes. Paris, France: OECD. https://www.oecdilibrary.org/docserver/62212c37-en.pdf?expires $=1622538706 \& i d=$ id\&accname=oid030093\&checksum =8A8FFE72C7741403825D0CC07026EF01

Ozgenel, M., \& Cetin, M. (2018). Development of the Marmara critical thinking dispositions scale: Validity and reliability analysis. International Journal of Eurasia Social Sciences, 9(32), 991-1015. http://www.ijoess.com/Makaleler/77393914_5.\%20991-1015\%20 mustafa\%20\%c3\%b6zgenel.pdf

Paul, R. (1990). Critical thinking: What every person needs to survive in a rapidly changing world. https://www.amazon.com/ Critical-Thinking-Survive-RapidlyChanging/dp/094 4583075

Pitpiorntapin, S., \& Topçu, M. S. (2016). Teaching based on socioscientific issues in science classrooms: A review study. KKU International Journal of Humanities and Social Sciences, 6(1), 119-136. http://www.resjournal.kku.ac.th/social/PDF/6_1_7.pdf

Pratiwi, Y. N., Rahayu, S., \& Fajaroh, F. (2016). Socioscientific issues (SSI) in reaction rates topic and its effect on the critical thinking skills of high school students. Jurnal Pendidikan IPA Indonesia, 5(2), 164-170. https://journal.unnes.ac.id/nju/index.php/ jpii/article/download/7676/5447

Puig, B., Blanco-Anaya, P., \& Pérez-Maceira, J. J. (2021). "Fake news" or Real Science? Critical thinking to assess information on COVID-19. Frontiers in Education, 6, 92. https://doi.org/10.3389/feduc.2021.646909

Ren, X., Tong, Y., Peng, P., \& Wang, T. (2020). Critical thinking predicts academic performance beyond general cognitive ability: Evidence from adults and children. Intelligence, 82, 1-10. https://doi.org/10.1016/j.intell.2020.101487

Sadler, T. D., Chambers, F. W., \& Zeidler, D. L. (2002). Investigating the crossroads of socioscientific issues, the nature of science, and critical thinking. Paper presented to the National Association for Research in Science Teaching, New Orleans, LA. https://files.eric.ed.gov/fulltext/ED466401.pdf

Sadler, T. D., \& Zeidler, D. L. (2005). The significance of content knowledge for informal reasoning regarding socioscientific issues: Applying genetics knowledge to genetic engineering issues. Science education, 89(1), 71-93. https://doi.org/10.1002/sce.20023

Sadler, T. D., Romine, W. L., \& Topçu, M. S. (2016). Learning science content through socio-scientific issues-based instruction: A multilevel assessment study. International Journal of Science Education, 38(10), 1622-1635. https://doi.org/10.1080/09500693.2016. 1204481

Salali, G. D., \& Uysal, M. S. (2020). COVID-19 vaccine hesitancy is associated with beliefs on the origin of the novel coronavirus in the UK and Turkey. Psychological medicine, 1-3. https://doi.org/10.1017/S0033291720004067

Salman, M., \& Yılmaz, A. (2021). The relationship between the attitude towards socioscientific issues and views on COVID-19 and vaccine. International Journal of Psychology and Educational Studies, 8(Special Issue), 83-98. https://dx.doi.org/10.52380/ijpes.2021.8.4.667

Shin, K. R., Lee, J. H., Ha, J. Y., \& Kim, K. H. (2006). Critical thinking dispositions in baccalaureate nursing students. Journal of Advanced Nursing, 56(2), 182-189. https://doi.org10.1111/j.1365-2648.2006.03995.x 
Sinatra, G. M., \& Lombardi, D. (2020). Evaluating sources of scientific evidence and claims in the post-truth era may require reappraising plausibility judgments. Educational Psychologist, 55(3), 120-131. https://doi.org/10.1080/00461520.2020.1730181

Sjöström, J., \& Eilks, I. (2018). Reconsidering different visions of scientific literacy and science education based on the concept of Bildung. Dori, Y. J., Mevarech, Z. R., Baker, D. R. (Eds.). In Cognition, metacognition, and culture in STEM education (pp. 65-88). Springer, Cham. https://doi.org/10.1007/978-3-319-66659-4

Tal, T., \& Kedmi, Y. (2006). Teaching socioscientific issues: Classroom culture and students' performances. Cultural Studies of Science Education, 1(4), 615-644. https://doi.org/10.1007/s11422-006-9026-9

Topçu, M. S. (2010). Development of attitudes towards socioscientific issues scale for undergraduate students. Evaluation \& Research in Education, 23(1), 51-67. https://doi.org/10.1080/09500791003628187

Topçu, M. S. (2019). Sosyobilimsel konular ve ögretimi (Socioscientific issues and teaching). Pegem Akademi. https://www.pegem.net/dosyalar/dokuman/2562021141149sosyobil imsel.pdf

Torres, N., \& Solbes, J. (2016). Contributions of intervention teaching using socioscientific issues to develop critical thinking. Enseñanza de las Ciencias, 34(2), 43-65. https://doi.org/10.5565/rev/ensciencias.1638

Tyrrell, D., \& Calinger, M. (2020). Breaking the COVID-19 Ice: Integrating socioscientific issues into problem-based learning lessons in middle school. In Proceedings of EdMedia + Innovate Learning (pp. 120-125). Online, The Netherlands: Association for the Advancement of Computing in Education (AACE). https://www.learntechlib.org/ primary/p/217293/.

Tsui, L. (1999). Courses and instruction affecting critical thinking. Research in Higher Education, 40(2), 185-200. https://doi.org/10.1023/A:1018734630124

Wang, H. H., Chen, H. T., Lin, H. S., Huang, Y. N., \& Hong, Z. R. (2017). Longitudinal study of a cooperation-driven, socio-scientific issue intervention on promoting students' critical thinking and self-regulation in learning science. International Journal of Science Education, 39(15), 2002-2026.

Williams, R. L., Oliver, R., \& Stockdale, S. (2004). Psychological versus generic critical thinking as predictors and outcome measures in a large undergraduate human development course. The Journal of General Education, 53(1), 37-58. https://www.jstor.org/stable/27797975?seq=1\#metadata_info_tab_contents

Wilson, J. A. (2018). Reducing pseudoscientific and paranormal beliefs in university students through a course in science and critical thinking. Science \& Education, 27(1), 183-210. https://doi.org/10.1007/s11191-0189956-0

Wineburg, S., \& McGrew, S. (2017). Lateral reading: Reading less and learning more when evaluating digital information. Teachers College Record. https://purl.stanford.edu/ yk133ht8603

Yacoubian, H. A. (2015). A framework for guiding future citizens to think critically about nature of science and socioscientific issues. Canadian Journal of Science, Mathematics and Technology Education, 15(3), 248-260. https://doi.org/10.1080/14926156.2015. 1051671

Yacoubian, H. A., \& Khishfe, R. (2018). Argumentation, critical thinking, nature of science and socioscientific issues: a dialogue between two researchers. International Journal of Science Education, 40(7), 796-807. https://doi.org/10.1080/09500693.2018.1449986

Yahaya, J. M., Zain, A.N.M., \& Karpudewan, M. (2015). The effects of socio-scientific instruction on pre-service teachers' sense of efficacy for learning and teaching controversial family health issues. International Journal of Science and Mathematics Education, 13(2), 467-491. https://doi.org/10.1007/s10763-014-9537-x

Yang, S. C., \& Chung, T. Y. (2009). Experimental study of teaching critical thinking in civic education in Taiwanese junior high school. British Journal of Educational Psychology, 79(1), 29-55. http://dx.doi.org/10.1348/000709907X238771

Zeidler, D. L., Lederman, N. G., \& Taylor, S. C. (1992). Fallacies and Student Discourse: Conceptualizing the Role of Critical Thinking in Science Education. Science Education, 76(4), 437-450. https://doi.org/10.1002/sce.3730760407

Zeidler, D. L., \& Nichols, B. H. (2009). Socioscientific issues: Theory and practice. Journal of Elementary Science Education, 21(2), 44-58. https://doi.org/10.1007/BF03173684 


\section{Öğretmen Adaylarunun Eleştirel Düşünme Eğilimleri ile Sosyobilimsel Konulara Yönelik Tutumları Arasundaki ilişkinin Incelenmesi}

\author{
Dr. Öğr. Üyesi Adem Yılmaz \\ Kastamonu Üniversitesi - Türkiye \\ ORCID: 0000-0002-1424-8934 \\ e-mail:yilmazadem@kastamonu.edu.tr
}

\author{
Dr. Öğr. Üyesi Muhammed Salman \\ Kastamonu Üniversitesi - Türkiye \\ ORCID: 0000-0003-2144-4842 \\ e-mail:msalman@kastamonu.edu.tr
}

\begin{abstract}
Özet
Bu çalışmada, öğretmen adaylarının eleştirel düşünme eğilimleri ile sosyobilimsel konulara yönelik tutumları arasındaki ilişki incelenmiştir. Araştırma sürecinde nicel araştırma yaklaşımlarından biri olan ilişkisel tarama yöntemi kullanılmıştır. Araştırmaya Türkiye'nin Karadeniz Bölgesi'ndeki devlet üniversitelerinin eğitim fakültelerinde öğrenim görmekte olan fen bilgisi, matematik, okul öncesi, psikolojik danışma ve rehberlik, sosyal bilimler, sınıf öğretmenliği ve güzel sanatlar bölümlerinden 813 öğretmen adayı katılmıştır. Araştırmada veri toplama aracı olarak eleştirel düşünme eğilimi ve tutum ölçekleri kullanılmıştır. Bulgular cinsiyet, sınıf düzeyi, sosyobilimsel konularda bilgi sahibi olma ve eğitim fakültesi bölümü değişkenleri dikkate alınarak incelenmiş̧ir. Elde edilen verilerin analizinde her bir ölçeğe ait sonuçlar önce düşük, orta ve yüksek puanlar olarak gruplara ayrılmıştır. iki kategorili değişkenler bağımsız örnekler $t$ testi kullanılarak, ikiden fazla kategoriye sahip değişkenler ise ANOVA testi kullanılarak analiz edilmiştir. Daha sonra çoklu doğrusal regresyon analizleri yapılmıştır. Araştırma sonuçlarını doğrulamak ve ileri istatistiklerle desteklemek için Hayes'in (2018) 1 numaralı regresyon modeli kullanılmıştır. Araştırma sonucunda düşük ve orta düzeyde eleştirel düşünme eğilimine sahip öğretmen adaylarının sosyobilimsel konulara yönelik tutumlarının da düşük olduğu ve alt değişkenlerin anlamlı bir fark yaratmadığı belirlenmiştir. Bu noktada eleştirel düşünme eğilimi düşük ve orta düzeyde olan öğretmen adaylarına bazı önerilerde bulunulabilir. Eğitim sürecinde sosyobilimsel konularda proje faaliyetlerine katılmaları sağlanabilir. Eleştirel ve analitik düşünme kapsamında derslerin alınması sağlanabilir. Eleştirel düşünme eğilimi yüksek olan öğretmen adaylarının sosyobilimsel konulara yönelik tutumlarının da yüksek olduğu görülmüştür. Ayrıca öğretmen adaylarının görüşlerinin bölüm, sinıf düzeyi ve sosyobilimsel konularda bilgi sahibi olma değişkenleri açısından anlamlı farklılı gösterdiği belirlenmiştir.
\end{abstract}

Anahtar Kelimeler: Eleştirel Düşünme Eğilimi, Sosyobilimsel Konular, ilişskisel Tarama, Regresyon Modeli

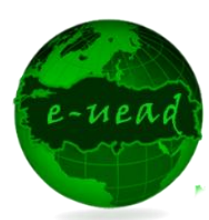

E-Uluslararası

Eğitim Araştırmaları Dergisi

Cilt: 13, No: 1, ss. 203-219

\section{Önerilen Atıf}

Yılmaz, A., \& Salman, M. (2022). Öğretmen adaylarının eleştirel düşünme eğilimleri ile sosyobilimsel konulara yönelik tutumları arasındaki ilişkinin incelenmesi. E-Uluslararası Eğitim Araştırmaları Dergisi, 13(1), $203-219$. DOI: https://doi.org/10.19160/e-ijer.1054393 


\section{Genişletilmiş Özet}

Problem Durumu: Özellikle son 30 yılda teknolojinin hızla gelişmesiyle insan yaşamının çarpıcı biçimde değiştiğini ve içinde bulunduğumuz çağın adının Paul'ün (1990) popüler kitabı olan Post-Truth olduğunu düşündüğümüzde eleştirel düşünme; "Hızla değişen bir dünyada her insanın hayatta kalması için gereken beceriler" arasında şüphesiz yerini almaktadır. Post-Truht dönemi gerçekten de bireylerin çeşitli türlerde kararlar alırken gerçeklerle aynı fikirde olmadığı ve test edilmiş ve onaylanmış bilgilerden ziyade kişisel inanç ve duygulara göre hareket ettiği dönemdir (Sinatra \& Lombardi, 2020). Bu dönemde 'bilgi güçtür' anlayışının önemini kaybettiği açıktır. Çünkü doğru ve yanlış bilgiyi ayırt etmek giderek zorlaşmaktadır (Wineburg \& McGrew, 2017). Ayrıca bilginin yanlış yorumlanması ve bilimsel kanıtların reddedilmesi, Post-Truth döneminin özellikleridir (Kienhues, Jucks \& Bromme, 2020). Araştırmacılar, yarının yetişkinlerinin karşılaşacakları varoluşsal krizler nedeniyle farklı sorunları çözmek zorunda kalacaklarını vurgulamaktadır (Abraham, 2016; Burnard, Colucci-Gray \& Sinha, 2021). O halde bu öngörüleri geleceğe en uygun şekilde yapmayı düşünmemiz gerekiyor. Aynı düşünce doğrultusunda Goodlad (1984) içinde bulunduğumuz sürecin canlıı̆̆ının altını çizerek eleştirel ya da üst düzey düşünmeyle meşgul olmayan ergenlerin geleceğin toplumu ve küreselleşmeye iyi hazırlanamayacağını söylemiştir. İklim değişikliği, genetiği değiştirilmiş organizmalar, aşılama gibi gerçek dünya sorunlarından oluşan Sosyobilimsel Konular (SBK), araştırmacılar tarafından vurgulanan sorunların başında gelmektedir (Tyrrell \& Calinger, 2020). Son yıllarda birçok ülke, tüm eğitim seviyelerinde eleştirel düşünme becerilerinin geliştirilmesine yardımcı olmaya çalışmaktadır (Facione, Sanchez, Facione \& Gainen, 1995; Ennis, 1996; Sadler, Chambers \& Zeidler, 2002; Yang \& Chung, 2009; Fong, Kim, Davis, Hoang \& Kim, 2017; Forawi, 2016; Chan, 2019; Janssen vd., 2019; Kavenuke, Kinyota \& Kayombo, 2020; McPeck, 2016; Ren, Tong, Peng \& Wang, 2020; Bellaera, Weinstein-Jones, Ilie \& Baker, 2021; Salman \& Yılmaz, 2021) ve sosyobilimsel konulara (Levinson, 2006; Chang \& Chiu, 2008; Topçu, 2019; Friedrichsen, Ke, Sadler \& Zagori, 2021) daha fazla önem vermeye başlamıştır. Artık Sosyobilimsel konular daha fazla öneme sahip olmaya başlamış ve ülkelerin ilgili eğitim programlarına entegre edilmeye başlanmıştır. Bu noktadan hareketle araştırmanın temel amacı, sosyobilimsel konuların eleştirel düşünmenin gelişmesine katkıda bulunacağı düşüncesinin incelenmesidir. Nitekim öğrencilerin eleştirel düşünmelerini geliştirmek akademik başarıları için çok önemlidir. Bunu yapmanın eğitimin kalitesini artıracağı genel olarak kabul edilmektedir (Ren vd., 2020). Literatürdeki çalışmaların büyük bir kısmı kapsamlı bir şekilde incelenmiş ve araştırmaların sosyobilimsel konuların eleştirel düşünmeyi geliştirmedeki önemine ve sosyobilimsel konularda karar vermede eleştirel düşünmenin önemine işaret ettiği gözlemlenmiştir. Sosyobilimsel konulara yönelik tutumlar ve eleştirel düşünme becerileri birbirini tamamlayan iki farklı bileşendir. Bu bileşenler, bireylerin olaylara farklı açılardan yaklaşmasını sağlamaktadır. Bireylerin topluma ayak uydurabilmeleri ve etkin vatandaşlık gösterebilmeleri için sosyobilimsel konulara yönelik belirli bir tutum düzeyine sahip olmaları gerekmektedir. Bu tutum, eleştirel ve sorgulayıcı düşünme yeteneği ile mümkün olmaktadır. Literatürde sosyobilimsel konu temelli uygulamaların eleştirel düşünme becerilerini dolaylı olarak artırdığı belirtilmektedir (Sadler vd., 2002; Zeidler \& Nichols, 2009; Domenech \& Marquez, 2013; Alfitriyani vd., 2021; Puig vd., 2021). Ancak alanyazın incelendiğinde sosyobilimsel konulara yönelik tutum ile eleştirel düşünme eğilimleri arasındaki ilişkinin yeteri kadar incelenmediği görülmüştür. Bu nedenle sosyobilimsel konu temelli uygulamalar ile eleştirel düşünme becerileri arasındaki ilişkinin doğrudan incelemesi yapılmıştır. Sosyobilimsel konu temelli uygulamalar ve eleştirel düşünme becerileri, bilimsel okuryazarlığın kazanılması için esastır. Bu amaçla bu çalışmada bu konu incelenmek istenmiş ve sosyobilimsel konulara yönelik tutumlar ile eleştirel düşünme eğilimleri arasında bir model kurulmaya çalışılımıştır.

Yöntem: Bu çalışmada nicel araştırma yaklaşımlarından ilişkisel tarama yöntemi kullanılmıştır. Genel olarak tarama yönteminde geniş kitlelere ulaşmak mümkündür ve bu nedenle araştırmacılara veri zenginliği ve diğer türden kolaylıklar sağladığı için literatürde sıklıkla tercih edilmektedir (Fraenkel, Wallen \& Hyun, 2019). Araştırmaya Türkiye'nin Karadeniz Bölgesi'ndeki devlet üniversitelerinde fen bilgisi, matematik, okul öncesi, psikolojik danışma ve rehberlik, sosyal bilgiler, sınıf öğretmenliği ve güzel sanatlar bölümlerinde okuyan 813 öğretmen adayı katılmıştır. Katılımcıların \%55,8'i $(n=453)$ kadın, $\% 44,2$ 'si ( $n=360)$ erkektir. Katılımcılar sınıf düzeyine göre incelendiğinde, \%21.64 ( $n=176) 1$. sınıf, \%24.84 $(n=202) 2$. sınıf, \%30.14 ( $n=245) 3$. sınıf, \%23,38'i $(n=190)$ ise 4. sınıfta bulunmaktadır. Araştırma sürecinde 
öğretmen adaylarına iki farklı ölçek uygulanmıştır. Bu ölçekler tutum ve eleştirel düşünme eğilimi ölçekleridir. Özetle, araştırma kapsamında öğretmen adaylarının eleştirel düşünme eğilimleri ve sosyobilimsel konulara yönelik tutumları farklı değişkenler dikkate alınarak incelenmiştir.

Bulgular, Sonuç ve Tartışma: Eğitim ve öğretim alanında bugüne kadar yapılan çalışmalarda önceliğin çoğu zaman akademik başarının nasıl artıılacağına odaklandığını biliyoruz. Bununla birlikte, günümüzün Post-Truth çağında, akademik başarı elde etmekten çok, dünyada yaşayan tüm insanları aynı anda etkileyebilen COVID-19 gibi pandemilerden nasıl kurtuluruz gibi konular kaçınılmaz olarak yerini almıştır. Hayatta kalmada başarının anahtarı, gerekli bilimsel bilgiyi kullanarak doğru kararları davranışa dönüştürmektir. Bu nedenle birçok ülke sosyobilimsel konuları ve eleştirel düşünceyi eğitim programlarına entegre etmenin aciliyetini fark etmiş ve bu yönde adımlar atmıştır (Bellaera vd., 2021; Chan, 2019; Forawi, 2016; Friedrichsen vd., 2021). Araştırma sonucunda öğretmen adaylarının sosyobilimsel konulara yönelik tutum ve eleştirel düşünme eğilimlerinin sınıf düzeyine, öğrenim gördüğü bölüme ve sosyobilimsel konulara ilişkin ön bilgilerine göre olumlu yönde anlamlı farklılık gösterdiği belirlenmiştir. Sınıf düzeylerine göre 1. sınıftan 4. sınıfa doğru artan hem sosyobilimsel konulara yönelik tutumların hem de eleştirel düşünme eğilimlerinin önemli olması, öğretmen adaylarının üniversite eğitimleri sırasında sosyobilimsel konular ve eleştirel düşünme konularında ders almaları ile açıklanabilir. Alanyazında bulunan diğer araştırmalarda da aynı doğrultuda sosyobilimsel konulara yönelik tutumların ve eleştirel düşünme eğilimlerinin sınıf düzeyine göre arttığı ortaya konmuştur (Shin, Lee, Ha \& Kim, 2006). Öğretmen adaylarının sosyobilimsel konulara yönelik tutumları ve eleştirel düşünme eğilimleri okudukları bölümlere göre incelendiğinde, fen bilgisi, matematik ve sosyal bilgiler bölümlerinde okuyanların diğer bölümlerde okuyanlardan daha yüksek ortalamalara sahip olduğu ortaya çıkmıştır. Fen bilgisi ve sosyal bilgiler öğretmenliği bölümlerinin müfredatlarına bakıldığında; "Bilimin Doğası; Eleştirel ve Analitik Düşünme; Çağdaş Dünya Sorunları; Bilim, Teknoloji ve Toplum" gibi derslerin bu bölümlerde öğrenim gören öğretmen adaylarının tutum ve eleştirel düşünme eğilimlerini etkilediği ve bu durumun diğer bölümlerde bulunan öğretmen adaylarına göre daha yüksek eğilim göstermelerine neden olduğu ifade edilebilir. Bu durum alanyazındaki bazı çalışma sonuçları ile desteklenmektedir (Topçu, 2019).

Sonuç ve Öneriler: Araştırma sonuçlarının eğitim bağlamlarına yansımaları şu şekilde listelenmiştir:

1. Öğretmen adaylarının eleştirel düşünme eğilimleri arttıkça sosyobilimsel konulara yönelik tutumları olumlu düzeyde artmaktadır. Buna karşın araştırmanın alt değişkenleri (cinsiyet, sınıf düzeyi ve benzerleri) genellikle düşük ve orta düzey eleştirel düşünme eğilimi olan bireyler için anlamlı bir fark yaratmamaktadır.

2. Sosyobilimsel konulara yönelik tutum davranışını en çok etkileyen değişken eğitim değişkenidir. Durum böyle olunca tutum düzeyleri en yüksek olan öğretmen adayları sırasıyla fen bilgisi, matematik ve sosyal bilgiler öğretmenliği olarak belirlenmiştir. Bu nedenle bu bölümler dışındaki bölümlerin öğretim müfredatlarında sosyobilimsel konulara ilişkin eleştirel ve analitik düşünme dersleri ve çeşitli uygulamalarına yer verilmelidir.

3. Öğretmen adaylarının sosyobilimsel konulara yönelik tutumlarını etkileyen bir diğer değişken de sınıf düzeyi değişkenidir. Sınıf düzeyi yükseldikçe öğretmen adaylarının tutumları ve eleştirel düşünme eğilimleri olumlu yönde artmaktadır. Bu nedenle öğretmen adaylarına üniversite eğitimleri boyunca ilk sınıftan son sınıfa kadar sosyobilimsel konular ve eleştirel düşünme becerileri ile ilgili etkinliklere katılmaları önerilebilir.

4. Bu çalışmada topluma nitelikli bireylerin yetiştirilmesinde görev alan öğretmen adayları tercih edilmiştir. Bununla birlikte, sosyobilimsel konulara karşı tutum ve eleştirel düşünme yeteneği, dünyada yaşayan tüm insanları ilgilendiren bir konudur. Bu nedenle ileriki çalışmalarda farklı fakültelerden ve hatta farklı yaşam alanlarından katılımcılar tercih edilebilir.

5. Araştırmanın bir diğer yönü ise üniversite öğrencileri ile yapılmış olmasıdır. Sosyobilimsel konular, ortaokul ve lise düzeyinde kazandırılması hedeflenen eleştirel düşünme becerileri ile yakından ilişkilidir. Bu nedenle çalışmanın ortaokul ve lise düzeyindeki öğrencilerle de yapılması faydalı olacaktır.

6. Son olarak, sosyobilimsel konular genellikle kesin bir çözümü olmayan ve toplumda kolayca uzlaşılamayacak konulardan oluşmaktadır. Bu noktada bireylerin eleştirel düşünmelerini sağlamak ve eleştiriye açık bir birey olarak yetiştirmek için erken yaşta pedagojik eğitime önem vermek gerekmektedir. 